\title{
BMJ Open Quality Assessing the utility of drug screening in the emergency: a short report
}

\author{
Anees Bahji, Tegan Hargreaves, Susan Finch
}

To cite: Bahji A, Hargreaves T, Finch S. Assessing the utility of drug screening in the emergency: a short report. BMJ Open Quality 2018;7:e000414. doi:10.1136/ bmjoq-2018-000414

Received 28 April 2018 Revised 9 0ctober 2018 Accepted 12 October 2018

Check for updates

(c) Author(s) (or their employer(s)) 2018. Re-use permitted under CC BY-NC. No commercial re-use. See rights and permissions. Published by BMJ.

Department of Psychiatry, Queen's University, Kingston, Ontario, Canada

Correspondence to

Dr Anees Bahji;

0ab104@queensu.ca

\section{INTRODUCTION}

Exposure to illicit drugs and alcohol is a major cause for visits to the emergency department (ED). ${ }^{1}$ For most drugs of abuse intoxication, ED physicians are sceptical to rely on the results of drug screens because immunoassays, although rapid and relatively cheap, have limitations in their sensitivity and specificity, and also carry relatively high rates of false positives and negatives. ${ }^{2}$ However, as it is often difficult to obtain the history from intoxicated patients, drug screens are still frequently ordered. With the emergence of Choosing Wisely, clinicians are becoming increasingly aware of the need to reduce the ordering of unnecessary tests. ${ }^{3}$ In this retrospective study, we explored the utility of drug screening in an acute care hospital ED to determine the frequency, patterns, indication and impact of drug screening for patients presenting with a mental health or addiction (MHA) chief complaint.

\section{METHODS}

Ethics approval was granted by the institutional review board of the primary research site. The Strengthening the Reporting of Observational Studies in Epidemiology guidelines for observational studies were followed. ${ }^{4}$ The charts of patients seen in the ED of a local hospital with an MHA chief complaint were retrospectively reviewed over a 3-month period (1 January to 31 March 2017), with the following data collected: chief complaint, demographics, clinical history, course in hospital, and drug screening history, including results, ordering service, rationale, and impact on diagnosis, management, and disposition.

\section{RESULTS}

Table 1 summarises the characteristics of our study sample $(n=323)$. The mean age of the sample was 31 (range: $7-88$ ). $57.0 \%$ of the sample was female, while $32.5 \%$ of the sample were students. Seventy-one per cent of the sample was unmarried, while $32 \%$ of the sample was unemployed. The top three chief complaints by frequency were suicidal ideation $(47.1 \%)$, psychosis $(16.7 \%)$ and disruptive or aggressive behaviour $(13.3 \%)$. Nineteen per cent were not on any psychotropic medication on presentation, and $29 \%$ denied any history of concurrent medical conditions (eg, diabetes, hypertension, dyslipidaemia). Twenty-five per cent reported a criminal history, while $93 \%$ reported a psychiatric history, however, only $18 \%$ reported a diagnosis of a substance use disorder. The three most frequently used substances were alcohol $(54.8 \%)$, marijuana $(46.1 \%)$ and tobacco $(37.5 \%)$. Sixty patients were tested with a blood alcohol level (BAL), of which $73 \%$ were negative. Ninety-two patients received a urine drug screen (UDS), of which $27 \%$ were negative. Twenty-nine patients received both BAL and UDS testing, of which $17 \%$ were double negative. BAL tests were ordered by the emergency medicine service $85 \%$ of the time, while UDS tests were ordered by the psychiatry service $65 \%$ of the time. When documented, the main indications for ordering were 'history of substance use' and 'rule out substance-induced psychosis'.

Of the 74 patients with identified substance-related diagnoses on discharge, 43 did not have a previous substance-related diagnosis. In all 43 cases where a new diagnosis was assigned, the information from the clinical history alone was sufficient in arriving at the diagnosis. In none of these 43 cases were the results of UDS and BAL required, and in many instances, the results of the test conflicted with the ultimate diagnosis.

\section{DISCUSSION}

Approximately one-third of the study sample received a drug screen, however, there were only two cases where drug testing was helpful in making a diagnosis (both were unconscious patients from whom history could not be obtained). For all other cases, drug screening did not impact the management of 


\begin{tabular}{|c|c|}
\hline Age (years) (mean \pm SD) & $31 \pm 17$ \\
\hline Range (years) & $7-88$ \\
\hline Gender: female (\%) & 57.00 \\
\hline \multicolumn{2}{|l|}{ Demographics (\%) } \\
\hline Student & 32.50 \\
\hline On ODSP & 20.40 \\
\hline Employed & 19.50 \\
\hline Married & 10.50 \\
\hline \multicolumn{2}{|l|}{ Chief complaint (\%) } \\
\hline Suicidal ideation & 47.10 \\
\hline Psychosis & 16.70 \\
\hline Disruptive/aggressive behaviour & 13.30 \\
\hline Mood/anxiety & 9.60 \\
\hline Overdose & 9.00 \\
\hline Homicidal ideation & 2.20 \\
\hline Other (delirium, functional decline) & 1.50 \\
\hline \multicolumn{2}{|l|}{ Medical/psychiatric history (\%) } \\
\hline Current psychotropic medication & 80.80 \\
\hline Concurrent medical diagnosis & 70.90 \\
\hline Concurrent psychiatric diagnosis & 92.90 \\
\hline Concurrent substance use disorder & 17.60 \\
\hline
\end{tabular}

Substance use (\%)

\begin{tabular}{|c|c|}
\hline \multicolumn{2}{|l|}{ Alcohol } \\
\hline Current & 41.2 \\
\hline Past & 54.80 \\
\hline \multicolumn{2}{|l|}{ Cannabis } \\
\hline Current & 36.80 \\
\hline Past & 46.10 \\
\hline \multicolumn{2}{|l|}{ Tobacco } \\
\hline Current & 32.20 \\
\hline Past & 37.50 \\
\hline \multicolumn{2}{|l|}{ Stimulants } \\
\hline Current & 14.90 \\
\hline Past & 25.40 \\
\hline \multicolumn{2}{|l|}{ Injection } \\
\hline Current & 4.60 \\
\hline Past & 5.90 \\
\hline \multicolumn{2}{|l|}{ Drug screening (\%) } \\
\hline Blood alcohol level (BAL) ordered & 19 \\
\hline Negative result & 73 \\
\hline Ordered by psychiatry & 15 \\
\hline Urine drug screen (UDS) ordered & 28 \\
\hline Negative result & 27 \\
\hline Ordered by psychiatry & 65 \\
\hline Both BAL and UDS ordered & 28 \\
\hline Double-negative result & 27 \\
\hline
\end{tabular}

ODSP, Ontario Disability Support Program. the patient; the clinical history formed the basis of the diagnosis, which was often incongruent with the drug screen results. Where patients reported recent polysubstance use, the drug screens were often negative, which highlights the significance of false negative results. Although an intoxicated patient's history is often felt to be unreliable, there were no cases when patients denied substance use with a corresponding positive drug screen.

Eighteen per cent of the study sample received a UDS to 'rule out a substance-induced psychosis', however, as substance use may follow psychosis, rather than be a driver a cause of psychosis, UDS tests cannot distinguish between these two scenarios. In most cases, the results of these tests added little to the clinical history, suggesting that overall, these tests were not useful in the ED. Additionally, the impact of the drug screen on clinical management was not clear. Of the 60 patients who received a BAL test, only five received treatment for potential alcohol withdrawal.

Still, drug screens can be helpful in outpatient addictions treatment, or in the prescribing of controlled substances. ${ }^{5}$ In these settings, drug screens can help improve patient care and communication by managing the misuse and diversion risks associated with controlled substances.

In a nutshell, while drug screens can be powerful tools, the ordering clinician should be aware of the potential pitfalls before ordering them and be able to appreciate what the test can and cannot reveal. Clinical history and exam continue to be the gold standards for making diagnoses in the ED.

Contributors SJF and AB planned the study. $A B$ and $T H$ conducted the study. $A B$ submitted the study.

Funding The authors have not declared a specific grant for this research from any funding agency in the public, commercial or not-for-profit sectors.

Competing interests None declared.

Patient consent Not required.

Ethics approval Queen's University Health Sciences Research Ethics Board. Provenance and peer review Not commissioned; externally peer reviewed. Open access This is an open access article distributed in accordance with the Creative Commons Attribution Non Commercial (CC BY-NC 4.0) license, which permits others to distribute, remix, adapt, build upon this work non-commercially, and license their derivative works on different terms, provided the original work is properly cited, appropriate credit is given, any changes made indicated, and the use is non-commercial. See: http://creativecommons.org/licenses/by-nc/4.0/.

\section{REFERENCES}

1 Calle PA, Damen J, De Paepe P, et al. A survey on alcohol and illicit drug abuse among emergency department patients. Acta Clin Belg 2006;61:188-95.

2 Beck O, Carlsson S, Tusic M, et al. Laboratory and clinical evaluation of on-site urine drug testing. Scand J Clin Lab Invest 2014;74:681-6.

3 Levinson W, Kallewaard M, Bhatia RS, et al. 'Choosing Wisely': a growing international campaign. BMJ Qual Saf 2015;24:167-74.

4 von Elm E, Altman DG, Egger M, et al. Strengthening the reporting of observational studies in epidemiology (strobe) statement: Guidelines for reporting observational studies. BMJ 2007;335:806-8.

5 Heit HA, Gourlay DL. Using urine drug testing to support healthy boundaries in clinical care. J Opioid Manag 2015;11:7-12. 